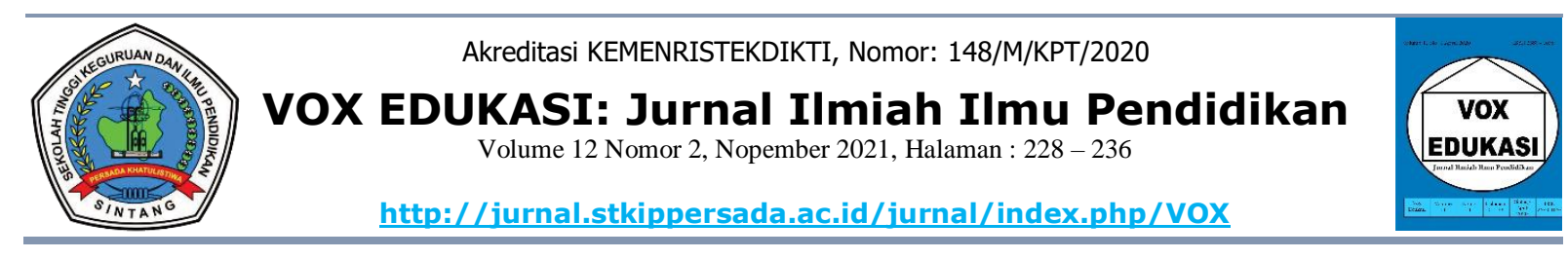

\title{
PROBLEM POSING DAN STRATEGI METAKOGNISI PESERTA DIDIK DALAM MATERI BANGUN RUANG DI SMK
}

\author{
Tanti Eviliana Pardede ${ }^{1}$, Sugiatno $^{2}$, \& Dede Suratman ${ }^{3}$ \\ 1,2,3 Magister Pendidikan Matematika FKIP, Universitas Tanjungpura Pontianak \\ Email: tanti.pardede05@gmail.com ${ }^{1}$, sugiatno@fkip.untan.ac.id ${ }^{2}, \underline{\text { d_suratman@yahoo.com }}{ }^{3}$
}

\section{INFO ARTIKEL \\ Riwayat Artikel: \\ Menerima : 29 September 2021 \\ Revisi : :01 Oktober 2021 \\ Diterima : 04 Oktober 2021}

\section{Kata Kunci:}

Problem Posing, Strategi

Metakognisi, Bangun Ruang

Sisi Lengkung

\begin{abstract}
ABSTRAK
Problem posing dan strategi metakognisi merupakan keterampilan berpikir tingkat tinggi dan sangat penting dikuasai oleh peserta didik. Penelitian ini bertujuan untuk mendeskripsikan kemampuan problem posing, strategi metakognisi peserta didik, hubungan kemampuan problem posing dan strategi metakognisi peserta didik. Penelitian ini menggunakan metode kombinasi sequential exploratory. Sumber data penelitian ini adalah peserta didik kelas XI Multimedia. Data berupa hasil tes uraian dan hasil wawancara semiterstruktur. Tes uraian terdiri sebanyak tiga soal yang meminta peserta didik untuk mengajukan masalah berdasarkan indikator situasi problem posing yang telah ditetapkan pada soal. Peserta didik diminta untuk mengajukan masalah matematis bangun ruang sisi lengkung pada situasi bebas, situasi semi-terstruktur, dan situasi terstruktur. Menyelesaikan masalah matematis bangun ruang sisi lengkung mengggunakan strategi metakognisi. Setelah itu akan dilakukan wawancara semi-terstruktur terhadap tiga peserta didik untuk memperdalam data dan mengungkap lebih lanjut mengenai kemampuan problem posing dan strategi metakognisi yang tidak terlihat pada hasil tes uraian. Kemampuan peserta didik dalam mengajukan masalah lebih dominan pada situasi bebas dan semi-terstruktur. Strategi metakognisi secara signifikan mempengaruhi kinerja aktual keterampilan pengajuan masalah dan penyelesaian masalah matematis. Hasil penelitian juga menunjukkan hubungan kemampuan problem posing dan strategi metakognisi dengan Pearson Correlation sebesar 0,72 yang berarti merupakan korelasi kuat dan memiliki hubungan yang positif.
\end{abstract}

\section{ABSTRACT}

Problem-posing and metacognition strategies are high-level thinking skills and are very important to be mastered by students. This study aims to describe problem-posing abilities, students' metacognition strategies, the relationship between problem-posing abilities and students' metacognition strategies. This study uses a sequential exploratory combination method. The data sources of this research are students of class XI Multimedia. The data are in the form of description test results and semi-structured interview results. The description test consists of three questions that ask students to pose problems based on the problem-posing situation indicators set on the questions. Students are asked to pose a mathematical problem of solid geometry in free situations, semistructured situations, and structured situations. They are solving mathematical problems of solid geometry using metacognition strategies. After that, interviews with three students will be conducted to deepen the data and reveal more about problem-posing abilities and metacognition strategies that are not seen in the results of the description test. The ability of students to pose problems is more dominant in free and semi-structured situations. Metacognition strategies significantly affect the actual performance of problem-posing and mathematical problem-solving skills. The results also show the relationship between problem-posing abilities and metacognition strategies with the Pearson Correlation of 0.72, which means it is a strong correlation and has a positive relationship. 


\section{PENDAHULUAN}

Problem posing merupakan keterampilan kognitif tingkat tinggi (Nardon dan Lee, 2011). Terminologi problem posing bermula dari bahasa Inggris, yang terbentuk dari kata "problem" yang bermakna masalah dan kata "pose" yang bermakna mengajukan (Jonassen, 2011, p. 1-3). Pengajuan masalah berkaitan erat dengan mengerjakan tugas matematis dan menghasilkan seperangkat pertanyaan (Collins dan O'Brien, 2003, p.282). Peserta didik diharuskan menguasai kemampuan untuk merumuskan dan menciptakan masalah sendiri berdasarkan situasi yang diberikan. Pentingnya problem posing, juga diungkapkan oleh para ahli di Nasional Council of Teachers of Mathematics (NCTM) bahwa kemampuan dalam mengajukan masalah matematis lebih penting dari pada hanya sekedar menyelesaikan persoalan matematis saja (NCTM, 1989; Afrilianto, 2019).

Setelah menyelesaikan masalah, biasanya seseorang tidak sepenuhnya memahami apa yang telah dilakukan sehingga akan mengajukan seperangkat pertanyaan yang baru untuk dianalisis (Brown dan Walter, 2005, 2005, p. 2-3). Kemampuan mengajukan masalah menjadi inti dalam pembelajaran matematika dan hakikat berpikir matematis (Cai, dkk, 2016; Bonotto, 2012). Pada dasarnya kemampuan mengajukan masalah matematis dianggap sebagai kebutuhan peserta didik untuk menunjang prestasi belajarnya (Afrilianto, 2019).

Istilah aktivitas pengajuan masalah merujuk pada aktivitas mereformulasi masalah dari suatu konteks atau masalah yang diberikan (Stickles, 2011). Berdasarkan beberapa studi terkait pengajuan masalah tersebut, maka ditarik kesimpulan bahwa kemampuan pengajuan masalah matematis adalah kapasitas seseorang untuk merekonstruksi suatu masalah matematis yang baru dalam bentuk pertanyaan melalui konteks matematis yang diberikan berdasarkan indikator situasi problem posing.

Pada prinsipnya, kurikulum 2013 membahas problem posing dan metakognisi dalam dokumennya. Dua di antara pakar pendidikan matematika yang sangat terkenal berasal dari Amerika Serikat, bernama Garofalo dan Letser dalam Journal for Research in Mathematics Education memaparkan pentingnya suatu metakognisi, dengan mengungkapkan adanya suatu dukungan yang berkembang mengenai pandangan jika hanya kemampuan kognisi saja dalam pembelajaran matematika tidak maksimal tanpa memperhatikan metakognisi (Shadiq, 2013).

Metakognisi memiliki peran penting dalam membantu peserta didik untuk mengevaluasi bagaimana cara menyusun gagasan agar lebih kompleks (Grotzer dan Mittlefehldt, 2012). Semakin besar kapasitas memori atau aspek metakognisinya maka semakin baik retensi dan pemahaman seseorang (Lehman, Goussions, \& Seufert, 2016). Metakognisi menekankan pada kesadaran tentang proses berpikir atau kognisi seseorang (Hiller, 2017, p. 14), regulasi berpikir (Wilson \& Conyers, 2016, p. 1), dan bagaimana hal itu digunakan untuk merencanakan, memonitor, 
mengevaluasi dan mengarahkan kembali berpikirnya seseorang (Taber, 2012, p. 157).

Strategi metakognisi dapat diartikan sebagai kegiatan yang digunakan dalam mengatur dan mengawasi pembelajaran (Brown, 1987). Strategi metakognisi merujuk pada kesadaran strategi kognitif seseorang untuk mencapai suatu tujuan tertentu, contohnya adalah ketika peserta didik mengajukan pertanyaan pada dirinya sendiri mengenai tugas dan setelah itu mengamati seberapa baik dirinya menjawab pertanyaanpertanyaan tersebut (Flavell, 1979).

Strategi metakognisi mengajarkan peserta didik mengenai pentingnya suatu langkah atau tahapan guna meningkatkan kesadaran pada proses berpikir dalam suatu pembelajaran, sehingga peserta didik dapat menyusun pikiran dengan mengawalinya pada tahap merancang, memonitor dan evaluasi (menilai apa yang telah dipelajarinya). Namun keterampilan strategi metakognisi ini umumnya tidak dianggap penting, sulit atau bahkan tidak berkembang dalam suatu proses pembelajaran matematis (Schoenfeld, 2016).

Fakta yang ada dilapangan berdasarkan hasil wawancara peneliti terhadap tiga peserta didik berprestasi dibidang akademik SMK Katolik Santa Maria Pontianak pada hari Senin, 3 Mei 2021 menurut keterangan ketiga peserta didik tersebut, mereka jarang mendapatkan pekerjaan sekolah atau pekerjaan rumah mengenai problem posing dan strategi metakognisi, bahkan asing dengan istilah tersebut. Hal ini menunjukkan bahwa problem posing dan strategi metakognisi di SMK
Katolik Santa Maria Pontianak menjadi hal yang asing.

Peserta didik terbiasa menerima soal-soal rutin dari bahan ajar atau buku cetak saja yang didalamnya tidak termuat hal-hal mengenai kemampuan problem posing dan strategi metakognisi. Bangun ruang telah menjadi topik materi yang menarik terhadap kajian pendidikan matematika dalam dekade terakhir ini (Juanti, dkk., 2021; Yudianto, dkk., 2021). Bangun ruang merupakan materi matematika dasar yang peserta didik sudah pelajari sejak di bangku SMP bahkan dipelajari lagi saat di SMK.

Berlandaskan pemaparan di atas, peneliti melihat adanya kesenjangan yang terjadi antara harapan dengan fakta di lapangan, karena alasan itulah peneliti terpicu untuk melaksanakan sebuah penelitian menggunakan judul "Problem Posing dan Strategi Metakognisi Peserta Didik dalam Materi Bangun Ruang Kelas XI SMK”.

Berdasarkan pemaparan latar belakang, diharapkan penelitian ini dapat (1) mendeskripsikan kemampuan problem posing peserta didik dalam materi bangun ruang sisi lengkung di SMK; (2) mendeskripsikan strategi metakognisi peserta didik dalam menyelesaikan permasalahan bangun ruang sisi lengkung di SMK; (3) mendeskripsikan hubungan kemampuan problem posing dan strategi metakognisi dalam materi bangun ruang sisi lengkung di SMK. 


\section{METODE PENELITIAN}

Penelitian ini mengimplementasikan metode penelitian kombinasi (mixed method), menggunakan exploratory sequential design, dimana pengumpulan data dan analisisnya diawali dengan pengumpulan dan analisis data kualitatif kemudian dilanjutkan dengan pengumpulan dan analisis data kuantitatif untuk menguji atau melakukan generalisasi berdasarkan temuan awal (Creswell, 2012).

Penelitian ini dilakukan di SMK Katolik Santa Maria Pontianak. Sumber data pada penelitian ini diperoleh dari 15 peserta didik kelas XI Jurusan Multimedia. Kemudian dipilih tiga peserta didik yang berprestasi untuk diberikan wawancara. Instrumen penelitian yang diterapkan pada penelitian ini telah dirancang melalui proses validasi oleh seorang dosen Magister Pendidikan Matematika FKIP Universitas Tanjungpura, seorang guru matematika di SMA Katolik Santu Petrus, dan seorang guru matematika di SMK Negeri 01 Pontianak.

Agar tidak timbul pemahaman yang berbeda pada istilah-istilah dalam penelitian, maka penting untuk menjabarkan sebuah definisi dari setiap variabel penelitian. Adapun definisi operasional variabel penelitian ini: problem posing adalah merumuskan dan mengajukan masalah matematis dari situasi yang diberikan, sedangkan kemampuan problem posing adalah kapasitas peserta didik dalam mengajukan masalah matematis bangun ruang sisi lengkung dalam tiga kategori situasi problem posing yaitu bebas, semi-terstruktur, dan terstruktur; strategi metakognisi adalah keterampilan yang melibatkan perencanaan, pemonitoran dan evaluasi terhadap aktivitas kognitif yang sedang dilakukan dalam menyelesaikan masalah matematis bangun ruang sisi lengkung; materi bangun ruang sisi lengkung membahas bangun ruang yang memiliki bagian berupa lengkungan (selimut atau permukaan bidang), bangun ruang sisi lengkung berupa tabung, kerucut, dan bola.

Meninjau hasil dari uji coba soal yang dilakukan di SMK Santa Monika diperoleh tingkat reliabilitas soal tes uraian tergolong sangat tinggi yaitu sebesar 0,97 , sedangkan untuk tingkat kesukaran soal tergolong sedang, dan tingkat daya pembeda soal tergolong sangat baik.

Prosedur yang diterapkan dalam penelitian ini meliputi tiga tahap berikut ini:

\section{Tahap Persiapan}

Langkah-langkah yang diimplementasikan pada tahap persiapan antara lain: (1) melaksanakan pra-riset di SMK Katolik Santa Maria Pontianak; (2) membuat instrumen penelitian berupa kisi-kisi rancangan instrumen kemampuan problem posing, kisi-kisi rancangan instrumen strategi metakognisi, kisikisi tes uraian kemampuan problem posing, tes uraian kemampuan problem posing, pedoman penskoran problem posing, pedoman penskoran strategi metakognisi, pedoman wawancara semi terstruktur kemampan problem posing, pedoman wawancara semi terstruktur strategi metakognisi; (3) melaksanakan seminar desaian penelitian; (4) merevisi desain penelitian; (5) melaksanakan uji validitas instrumen penelitian; (6) merevisi hasil uji 
validitas instrumen penelitian;

melaksanakan uji coba soal atau pra-riset di SMK Santa Monika; (8) menganalisis data hasil uji coba soal; (9) merevisi instrumen penelitian berdasarkan hasil uji coba; (10) membuat surat izin untuk mengadakan riset di SMK Katolik Santa Maria Pontianak.

\section{Tahap Pelaksanaan}

Langkah-langkah yang diimplementasikan pada tahap pelaksanaan dalam penelitian ini antara lain: (1) memberikan tes uraian problem posing kemudian menyelesaikan masalah matematis dengan strategi metakognisi pada peserta didik; (2) melakukan wawancara mengenai kemampuan problem posing peserta didik; (3) melakukan wawancara mengenai strategi metakognisi peserta didik; (4) mengumpulkan dokumen-dokumen yang dianggap penting dalam penelitian dengan melakukan dokumentasi.

\section{Tahap Akhir}

Langkah-langkah yang diimplementasikan pada tahap akhir dalam penelitian ini antara lain: (1) mengolah, menganalisis data kemudian mendeskripsikan data secara kualitatif; mengolah, menganalisis data kemudian mendeskripsikan data secara kuantitatif; (3) menyusun laporan penelitian.

\section{HASIL DAN PEMBAHASAN}

\section{Hasil Penelitian}

Data penelitian yang diperoleh berasal dari hasil tes uraian dan wawancara peserta didik dalam materi bangun ruang sisi lengkung. Hari pertama penelitian dilaksanakan pada tanggal 8 Juni 2021, peserta didik berjumlah 15 orang dari kelas XI Multimedia SMK Katolik Santa Maria Pontianak diberikan tes uraian sebanyak tiga item soal pengajuan masalah matematis bangun ruang sisi lengkung, yang setiap soalnya memuat masing-masing indikator situasi problem posing yaitu soal pertama dengan situasi bebas, soal kedua dengan situasi semi-terstruktur, dan soal ketiga dengan situasi terstruktur.

Setelah itu peserta didik diminta untuk menyelesaikan masalah matematis bangun ruang sisi lengkung yang telah mereka ajukan dengan menerapkan strategi metakognisi. Hasil tes uraian disajikan pada Tabel 1

Tabel 1. Hasil Tes Uraian Problem Posing dan Strategi Metakognisi

\begin{tabular}{cccc}
\hline \multirow{2}{*}{ No } & Kode Peserta Didik & \multicolumn{1}{c}{ Nilai } \\
\cline { 3 - 4 } & & $\begin{array}{c}\text { Pengajuan Masalah } \\
\text { Matematis }\end{array}$ & $\begin{array}{c}\text { Penyelesaian Masalah dengan Strategi } \\
\text { Metakognisi }\end{array}$ \\
\hline 1 & AW & 90 & 90 \\
2 & CT & 80 & 80 \\
3 & CCL & 65 & 20 \\
4 & CG & 65 & 65 \\
5 & CMY & 100 & 100 \\
6 & EA & 80 & 80 \\
7 & JA & 80 & 80 \\
9 & JJV & 100 & 100 \\
10 & JN & 90 & 80
\end{tabular}




\begin{tabular}{cccc}
11 & NG & 90 & 90 \\
12 & RRF & 65 & 65 \\
13 & SA & 80 & 35 \\
14 & TW & 65 & 65 \\
15 & YS & 100 & 100 \\
\hline
\end{tabular}

Masalah matematis yang telah peserta didik ajukan dalam materi bangun ruang sisi lengkung selanjutnya akan dianalisis guna mendeskripsikan kemampuan problem posing peserta didik. Sedangkan penyelesaian dari masalah matematis tersebut akan dianalisis guna melihat strategi metakognisi peserta didik. Tampak dari tabel 1 hasil tes uraian sebanyak empat peserta didik mendapatkan nilai dibawah KKM.

Analisis data dalam kemampuan problem posing dan strategi metakognisi dilakukan secara kualitatif, untuk itu peneliti melakukan wawancara terstruktur terhadap tiga orang peserta didik guna memperdalam data dan mengungkap lebih lanjut data mengenai kemampuan problem posing dan strategi metakognisi peserta didik yang tidak terlihat pada hasil tes uraian.

Hubungan problem posing dan strategi metakognisi akan diketahui melalui uji korelasi Pearson. Hasil uji korelasi Pearson menunjukkan $r_{\text {hitung }}\left(r_{x y}\right)$ sebesar 0,72 dengan taraf signifikan $(\propto)=0,05$, sedangkan $r_{\text {tabel }}$ sebesar 0,51. Oleh karena $r_{\text {hitung }}(0,72)>$ $r_{\text {tabel }}(0,51)$ maka terdapat hubungan yang positif dan signifikan antara variabel problem posing dan strategi metakognisi.

\section{Pembahasan}

Penelitian ini akan mendeskripsikan mengenai kemampuan problem posing peserta didik, strategi metakognisi peserta didik, dan mendeskripsikan bagaimana hubungan kemampuan problem posing dan strategi metakognisi peserta didik dalam materi bangun ruang sisi lengkung. Hasil penelitian ini sejalan dengan penelitian terdahulu yang menyatakan bahwa kemampuan problem posing penting untuk dimiliki dan dikuasai (Afriansyah, 2017); strategi metakognisi memiliki peran sebagai acuan dalam memperoleh pembelajaran yang efektif (Toit \& Kotze, 2009).

Berikut akan dideskripsikan secara rinci hasil penelitian yang diperoleh:

\section{Kemampuan Problem Posing}

Berdasarkan data hasil tes uraian dan wawancara dari tiga peserta didik dalam mengajukan masalah matematis bangun ruang sisi lengkung mendapatkan kesimpulan bahwa dalam pengajuan masalah pada soal pertama dengan situasi bebas dan soal kedua dengan situasi semi-terstruktur dapat dikerjakan dengan lancar dan tepat, namun pada soal ketiga dimana diminta untuk mengajukan masalah pada situasi terstruktur satu dari tiga peserta didik yang diwawancara mengalami kesulitan sehingga tidak sesuai dengan indikator pada situasi terstruktur dalam problem posing. 
Kemampuan peserta didik dalam mengajukan masalah matematis lebih dominan pada situasi bebas dan situasi semi-terstruktur. Pengajuan masalah matematis merupakan sebuah pengalaman baru bagi peserta didik. Kemampuan dalam mengajukan masalah matematis dan kemudian menyelesaikan sendiri masalah matematis tersebut dipercaya lebih berarti dibanding hanya sekedar menyelesaikan masalah matematis yang sudah ada dibuku paket.

\section{Strategi Metakognisi}

Setelah peserta didik mengajukan masalah matematis bangun ruang sisi lengkung, maka selanjutnya mereka akan diminta untuk menyelesaikan masalah matematis yang telah mereka ajukan tersebut. Berdasarkan hasil tes uraian dan wawancara terhadap ketiga peserta didik tersebut disimpulkan bahwa mereka dapat menyelesaikan masalah matematis dengan melakukan atau menerapkan langkah-langkah seperti: perencanaan, pemonitoran, dan evaluasi. Strategi metakognisi secara signifikan dapat mempengaruhi kinerja aktual keterampilan pengajuan masalah dan penyelesaian masalah matematis bangun ruang sisi lengkung. Ini membuktikan bahwa strategi metakognisi sangatlah penting dikuasai oleh peserta didik.

\section{Hubungan Kemampuan Problem Posing dan}

\section{Strategi Metakognisi}

Hasil tes uraian peserta didik dalam mengajukan masalah dan menyelesaikan masalah matematis bangun ruang sisi lengkung yang akan digunakan untuk melihat korelasi dari kedua variabel tersebut. Berdasarkan hasil uji analisis korelasi Pearson dengan perhitungan manual maupun menggunakan aplikasi SPSS tampak bahwa nilai signifikansi sebesar 0,02 yang artinya nilai signifikansi tersebut lebih kecil dari 0,05 sehingga dapat disimpulkan bahwa kedua variabel tersebut yaitu kemampuan problem posing dan strategi metakognisi berkorelasi. Selanjutnya dilihat dari nilai Pearson Correlation yaitu sebesar 0,72 yang berarti merupakan korelasi kuat dan memiliki hubungan yang positif.

Berdasarkan hasil penelitian terdahulu oleh Ghasempour, Bakar, dan Jahanshahloo mengenai Mathematical Problem Posing and Metacognition: A Theorical Framework menyajikan perspektif pedagogis tentang pengajuan masalah dan pendekatan metakognisi. Hasil penelitian yang menyatakan guru memiliki peran sebagai pembimbing strategi metakognisi sebagai penopang untuk mengembangkan kinerja peserta didik dalam mengajukan masalah matematis (Ghasempour, Bakar \& Jahanshahloo, 2013). Peserta didik yang memiliki strategi metakognisi baik, maka dapat mengajukan masalah matematis dengan baik pula. Ini menunjukkan penelitian ini terkonfirmasi oleh penelitian terdahulu bahwa benar adanya hubungan yang tergolong kuat antara problem posing dan strategi metakognisi.

\section{SIMPULAN}

Kemampuan problem posing peserta didik yang dikatakan baik adalah peserta didik 
mampu mengajukan masalah matematis pada setiap indikator situasi problem posing yaitu situasi bebas, situasi semi-terstruktur, dan situasi terstruktur. Strategi metakognisi merupakan bagian penting bagi peserta didik dalam menyelesaikan masalah matematis, membantu peserta didik untuk belajar matematika secara efektif. Strategi metakognisi mengajarkan peserta didik untuk melakukan perencanaan, pemonitoran, dan evaluasi. Problem posing dan strategi metakognisi memiliki hubungan yang kuat, hal ini dapat dilihat dengan adanya hasil korelasi Pearson yang menunjukkan adanya hubungan positif dan signifikan, serta nilai korelasi yang tergolong tinggi.

Peneliti menganjurkan beberapa saran yang dapat diperhatikan dan dipertimbangkan sebagai berikut: (1) bagi guru matematika diharapkan untuk mempertimbangkan hasil penelitian ini dan menjadikannya sebagai bahan acuan dalam pembelajaran matematika yang berguna untuk meningkatkan kemampuan problem posing dan strategi metakognisi peserta didik saat proses pembelajaran; (2) bagi peneliti lain yang tertarik melanjutkan penelitian ini dianjurkan untuk melakukan pengembangan media pembelajaran matematis berbasis kemampuan problem posing dan strategi metakognisi.

\section{DAFTAR RUJUKAN}

Afriansyah, E. (2017). Problem Posing Sebagai Kemampuan Matematis. Jurnal Mosharafa. 6(1): 163-180
Afrilianto et al. (2019). Improving Students' Mathematical Problem Posing Ability Using PACE Model. Journal of Physics. Doi: 10.1088/17426596/1315/1/012007.

Bonotto, C. (2012). Artifacts as sources for problem-posing activities. Educ Stud Math, 83: 37-55. Springer Science dan Business Media Dordrecht. Doi: 10.1007/s10649-012-9441-7

Brown. (1987). Enhancing Instructional Time Through Attention to Metacognition. Journal of Learning Dsabilities, 20(2): 66-75. doi: $10.1177 / 002221948702000201$.

Brown, S. I., \& Walter, M, I. (2005). The art of problem posing ( $3^{\text {rd }}$ ed.) Mahwah, New Jersey: Lawrence Erlbaum Associates Publishers.

Cai, J., dan Hwang, S. (2016). Generalized and generative thinking in U.S. and Chinese students' mathematical problem solving and problem posing. Journal of Mathematical Behavior, 21(4), 401-421.

Cai, J., John, C., Wang, N., Hwang, S., Nie, B., dan Garber, T. (2012). Mathematical problem posing as a measure of curricular effect on students' learning. Educ Stud Math, 83: 57-69. Springer Science dan Business Media B. V. doi 10.1007/s10649-012-9429-3

Collins, J. W., \& O'Brien, N. P. (2003). The greenwood dictionary of education. London: Greenwood Press.

Creswell, J. W. (2014). Research design qualitative, quantitative and mixed method approaches. London: Sage.

Flavell, J. H. (1979). Metacognition and cognitive monitoring: A new area of cognitive-development inquiry. American Pshycologist, 34(10), 906$911 . \quad$ doi:10.1037/0003006X.34.10.906 
Ghasempour, Z., Bakar M. N., dan Jahanshahloo, G. B. (2013). Mathematical problem posing and metacognition: a theoretical framework. International Journal of Pedagogical Innovations, 1, No. 2, 6368.

http://dx.doi.org/10.12785/ijpi/010201

Grotzer, T. dan Mittlefehldt, S. (2012). The role of metacognition in students' understanding and transfer of explanatory structures in science. In A. Zohar dan Y. J. Dori (Eds.), Metakognitive in science education: Trends in current research (pp. 79-99). Dordretch: Springer. doi:10.1007/97894-007-2132-6_5

Hiller, S. E. (2017). Mastering science with metacognitive and self-regulatory strategies: A teacher-resercher dialogue of practical application for adolescent student. New York, NY: Nova.

Jonassen, D. H. (2011). Learning to solve problems: A Handbook for designing problem-solving learning environments. New York, NY: Routledge.

Juanti, dkk. (2021). Analisis Kesulitan dalam Menyelesaikan Soal Geometri Pokok Bahasan Bangun Ruang Sisi Datar. Jurnal Pembelajaran Matematika Inovatif. doi: 10.22460/jpmi.v4i2.239248.

Lehman, J., Goussios, C., \& Seufert, T. (2016). Working memory capacity and disfluency effect: An aptitudetreatment- interaction study. Metacognition Learning, 11(1), 89105. doi: 10.1007/s11409-015-9149-Z

Nardon, C. F., \& Lee R. G. (2010). Critical inquiry across the disciplines: Strategy student-generated problem posing. College Teaching, 59(1), 13-22. doi: $10.1080 / 87567555.2010 .489077$
National Council of Teachers of Mathematics. (1989). Curriculum and Evaluation Standards for School Mathematics. Reston, VA. Author.

Schoenfeld. (2016). Learning to Think Mathematically: Problem Solving, Metacognition, and Sense Making in Mathematics. Journal of Education, 196(2), 1-38

Shadiq, F. (2013). Metakognisi: Apa dan Mengapa Penting? PPPPTK Matematika. http://p4tkmatematika.kemendikbud.g o.id

Stickles, P. R. (2011). An analysis of secondary and middle school teachers' mathematical problem posing. Investigations in Mathematics Learning, 3(2), 1-34. doi:10.1080/24727466.2011.11790301

Taber, K. S. (2012). Modelling Learners and learning in science education: Developing representation of concepts, conceptual structure and conceptual change to inform and research. Dordrecht: Springer. doi:10.1007/97894-007-7648-7

Toit \& Kotze. (2009). Metacognitive Strategies in the Teaching and Learning Mathematics. Faculty of Education, University of the Free State. Pythagoras, 70, 57-67

Wilson, D., dan Conyers, M. (2016). Teaching students to drive their brains: Metacognitive strategies, aactivites, and lesson ideas. Alexandria, VA: ASCD.

Yudianto, E., Nindya, Y. S., \& Setiawan, T. B. (2021). Kecemasan Geometri Siswa dalam Menyelesaikan Masalah Bangun Ruang Sisi Datar Ditinjau dari Teori Van Hiele. Jurnal Cendikia: Jurnal Pendidikan Matematika. 05(02), 11021115 